\title{
Literary Translation Between Albania and SpainA Cultural Bridge Between Two Countries
}

\author{
Flavia Kaba, Ph.D. \\ Department of Spanish Language, Faculty of Foreign \\ Languages, University of Tirana, Albania
}

\begin{abstract}
The present paper aims to evidence the literary translation as a cultural bridge between the two countries, Albania and Spain. It is a topic which has interests in terms of literary translation because the literary translation Albanian-Spanish and vice versa is a non-treated topic in our country. Literature is a bridge between the two countries and language possesses all the characteristics of culture, because when it is translated it is produced an exchange of linguistic systems. In this paper, we will present chronological data on the number of literary translations in both countries, respectively in Albania and Spain, and we will explain the importance of literary translation as a process that connects cultures, inasmuch as the literary translation aims to transfer literary or artistic experiences of a culture to another culture. Moreover, this paper will provide an overview of the impact of literary translation in both cultures, Albanian and Spanish.
\end{abstract}

Keywords: literary translation, culture values, Albania, Spain.

\section{Introduction}

\section{An overview of Spanish in Albania}

According to the report of Cervantes Institute of 2016, Spanish language is a native language for more than 472 million people and a second most spoken language in the world after mandarin Chinese. ${ }^{1}$ Spoken in 21 countries, recently Spanish has become a language which is requested in Albanian schools and universities. Spanish became for the first time, part of the "Asim Vokshi" high school curriculum in 1979-1980, to be interrupted after 4 years and then to be part of the curriculum again after 1990. Spanish was taught only in this high school until 2007. One year later, the Spanish embassy enabled the opening of the Department of Spanish in the Faculty of Foreign Languages, in the University of Tirana. With the opening of this department and the support of the Spanish embassy, the department could draw a cooperation project with some universities in Spain. Titled "Fortalecimiento del Departamento de Español de la Facultad de Lenguas Extranjeras de la Universidad de Tirana', this Project was financed by the Spanish Agency of International Cooperation and Development (AECID). The Project planned programs that could come to help to the syllabuses, but also the specialization of the staff, and also the supply with necessary didactic materials, dictionaries, digital tables (boards), etc. In order to implement this Project, a very important part was on the cooperation with the International University Menendez Pelayo (UIMP). With the opening of the department of Spanish, the number of students enrolled was 40 , the lowest number in the faculty. With the passing of the years, the number was increasing and today the number of students enrolled is 75 , exceeding the number of students enrolled in Turkish, Greek or Russian. The interest of students to learn this foreign language is increasing, as it is increasing the number of students in other departments of the Faculty of Foreign Languages, who choose Spanish as a second language to learn.

\section{Tendencies of translation, then and now (yesterday and today)}

As we all know, from the practices of cultural communication, at different periods and places, translation has played an important role in human history development, in various relations among peoples, as well as in forwarding scientific and literary knowledge among them. Without translation, this great bridge of communication in the civilized world, this picture of extraordinary achievements in civilization, we wouldn't have the possibility to discover values of languages and spaces,

${ }^{1}$ El espanol: lengua viva. Informe 2016, Instituto Cervantes, http://ëëë.cervantes.es/imagenes/File/prensa/EspanolLenguaViva16.pdf 
at different periods of time and at different written models. Moreover, without the mediation of translation, as a possibility of communication extension, thus exchanging values, it wouldn't be possible for the cultural integration of different settings, as an edge of spiritual values intercommunication of different peoples and cultures.

Besides being an interconnectivity bridge, translation serves also as a mirror where there are generally reflected changes happened during the years, but also where the verification of achievements and changes of different cultures happened and also the process of mutual exchange happens. However, the discipline of translation of literary works is now a real scientific discipline with a well-defined object, what has enabled the contact of most important moments in culture, science and literature. We shall not forget that the symbol of this process is the Babel Tower, thus the need of people to "decode" messages different languages transmit. This made it possible that individuals, through translation, come into knowing the culture, literature and scientific achievements. Besides the great steps on the last years on intercultural, interlinguistic and interspatial relations and achievements in art, science, politics and economy, the real creator in translation, which is already a real scientific discipline and which works on bases of well-defined standards, is Saint Jerome, the father of the Church, who, even though being alone in Belen, in the end of the fourth century dedicated to the translation of the Bible in Latin, a task which took 30 years. With this oeuvre, he put the foundations of translation and the weaknesses of cultural intercommunication. As a theoretical result of this extraordinary and preliminary effort, but also as a result of the practice gained in translation, Saint Jerome left a legacy for the future of human civilization, a document which explains the tendency for interpretation, which is titled "Letter for Pammaquio".

In this uncommon letter of its kind, with wide mythological submissions and of an explicit nature, among many things, he speaks of the principles and methods of translation, with which he would build the first translation poetics: De optimo genere interpretandi (On the best way of translating). ${ }^{1}$

Writings on translation, as an interconnectivity bridge and as a communication picture, are as old as the century which forwards the Christian epoch. The need for communication among cultures made translation a window where to see the civilized world from. The writings of Cicero, Horacio and Saint Jerome (4th century A.D.) had a great influence on intercultural communication settings until the 20th century. ${ }^{2}$

They have enabled the developments in science, culture and literature, as a process without which peoples would not have the possibility to come into contact with progress. Even though the practices of translation date back many years, its study as a special discipline in the institutions of higher education do not date back than the second half of the $20^{\text {th }}$ century. ${ }^{3}$ It is noticed a great contradiction between translation as a living process, the contact with a different culture and the aspect of study, the diffraction and perfecting of communication methods through translation. On the other hand, this act has not been given the place deserved, as a means and extraordinary way of communication between edges of civilizations. After a very long way from century to century, from one stage to another, translation has the status of a special discipline, which is studied and analyzed scientifically only in the $20^{\text {th }}$ century, carrying also the delays and unavoidable lacks. During 1950 s and '60s of the last century, a translation study, far from the idea to be an autonomous discipline, was considered as a branch of applied linguistics. ${ }^{4}$ At the end of Second World War, we find the first works which carry the problem of translation, as a practice and method which needs to be defined in all its aspects, as a clear situation when the debate started for the level of translating different works, for the methodology and various forms. Translation, even though it was considered as a sub-issue of linguistics, thus leaving it again under the shadows of linguistics, when in fact in its content, structure and function, with the aspects it represents, is broader and much more specific as a process. There are many ideas and discussions on translation, on the ways and models, but the right definition on its nature seems to be the one from the American linguist Eugene Nida: Translating consists in reproducing in the receptor language the closest natural equivalent of the source language message, first in terms of meaning and secondly in terms of style. ${ }^{5}$ Symbolized already as connecting bridges or as a necessary means for cultural exchanges and seen more as an unavoidable need which grows from day to day, translation as an open act and process is a worldwide phenomenon, which is studied in all its

\footnotetext{
1Salinas Viereck, Roberto, La traduccion como instrumento y estetica en la literatura hispanoamericana del siglo XVI, Universidad Complutense de Madrid, 2003, p. 43.

${ }^{2}$ Ajazi, Edlir, Aspekte teorike dhe praktike të përkthimit, Universiteti Tiranës, p. 2.

${ }^{3}$ Ajazi, Edlir, Aspekte teorike dhe praktike tëpërkthimit, Universiteti Tiranës, Tiranë, p. 2.

4Luis Estevez, Jose Alberto, Las traducciones escritas de letras de canciones: Bob Dylan en Espana (1971- 2006), Universidad de Laguna, Curso 2009/2010, Tesis Doctorales, p. 24.

5Nida, Eugene Albert, Language Structure and Translation: Essays, Stanford University Press, California, 1975, p. 33.
} 
stages, but which seems that it hasn't still found an ultimate and complete definition. But, it is still in the beginnings of building a unity theory of translation, based on scientific foundations, able to clarify in all aspects - communicative, pragmatic, linguistic and especially aesthetic - that very complicated process which we call in a very simple term: translation. ${ }^{1}$ Translation is a very complex process that implies the transmission of information between different languages, spaces and nations, which often encounters major difficulties of the nature of a single value, i.e. semantic and aesthetic compatibility of words of different languages, therefore, often used the expression traduttore / traditore, translator / traitor. In fact, the translation of any nature whatsoever, has its difficulties, especially when cultures are far from each other, not only geographically, but more on that civilization and cultural aspects. A good example of this can be the case when an Albanian interpreter tries to bring in Albanian translation of the fall of snow in Alaska, the coldest place in America, where the temperature can mark the -60 degrees Celsius, and the land itself has several kinds of descriptions for the word snow itself or the type of its fall. Many theorists in translation, already viewed it as a process that also consists of translation criticism, have explored the inside and tried to see it from an interdisciplinary, autonomous and scientific perspective, as an approach that enables expansion communication spaces with the process itself. Vinay and Darbelnet define translation as "transition from language A to B language to express the same reality" while Catford argues that translation represents "the replacement of textual material in another language." 2 While Eugenio Coserio is of the opinion that the translation from a linguistic point of view means to reproduce in another language, maintaining the unique and transforming what is inevitable. The philosopher George Steiner notes that translation is the behavior of the silent mode in the active state of a given situation or text, that happens in intercultural relations. Until the twentieth century translation was seen by more as an almost exclusively philological perspective, being away from the objective of the field representing. With the proliferation of Russian formalism, structuralism and subsequently, the translation concept continued to be treated in a manner distinct from linguistics, while the theory of communication led to the adoption of sociolinguistics and psychology related disciplines, which reassessed the translation act. Nowadays modern disciplines, such as comparative stylistics, comparative literature, semantics, grammar and systemic, communication theories, cognitive theories join the discipline in question, but none of them fully includes it. ${ }^{3}$ Discourse on what translation represents, in practical terms, and proper theoretical marking, remains open, being perfect every day, but the research aspect does not follow the pace of the act of translation. If you add the other fact, namely the translation theory as an inevitable act that deals with early modeling and presents the different schools of translation, along the long route that has been translated as an autonomous process and is so well blessed in all meanings of various alloys and various science, culture, art and literature, problems come up and it becomes more complex.

\section{Translation of literary works from Spanish and vice versa}

According to a study carried out in the terrain, in some of the most important institutions, as the National Library and the Library of the Faculty of History and Philology, but also with the support of some publishing houses in Tirana, the number of translations from Spanish to Albanian is 135. This is a higher figure compared to that of Albanian works translated into Spanish, which is 74 . The first translation from Spanish to Albanian dates back to 1928 , of the novel 'El ingenioso Hidalgo Don Quijote de la Mancha', Miguel de Cervantes de Saavedra, which was translated from the literature professor from Shkodra and at the same time translator, Ndoc Vasija. For the Albanian reader, this was the first introduction to "Don Quijote" but also to the first Spanish translations. Some years later, in 1932, the translation of Don Quijote would come to Albanian from another translator, poet and famous diplomat, Fan S. Noli. For the Albanian press of those years, translating to Albanian this representative novel of Spanish literature, brought a lot of discussions, but people were also enthusiastic about this world oeuvre which could not lack in Albanian. In "Republika" newspaper of Boston, on October, 22 ${ }^{\text {nd }}, 1931$, the columnist nicknamed "The Student" writes an article called "Don Quijote and Albania". With a very enthusiastic language, he expresses his joy that this novel is coming to Albanian, and introduces also the values of the translator, the importance of its translation for Albania and Albanians. "We definitely believe that this "plume knight" which is bringing to Albanian the masterpiece of Cervantes, for the good of all Albanians, and not only for those who want to die for Albania." 4 The following

1Pema, Alket, "Mbi përkthimin në gjuhën shqipe të poezisë sëUolt Uitmanit", Universiteti Tiranës, 2014, p.7.

2Llacer Llorca, Eusebio, Sobre la traduccion: Ideas tradicionales y teorias contemporanes, Universitat de Valencia, 2004, p.179.

${ }^{3}$ Vukovic, Jovanka, Como definimos el concepto de traduccion?, Cagnolati, Beatriz. La Traductologia: Miradas para comprender su complejidad, Universidad Nacional de La Plata, 2012, p.11-12.

${ }^{4}$ Nushi, Admira. Don Kishoti, ky humbës fitimtar. Tezë doktorature, Universiteti Tiranës, 2015, p. 41 
years would bring other translations of Spanish literature, by broadening the cultural and literary horizon of Albanians towards the Spanish country. We can mention here some of the Spanish writers who were brought masterfully in Albanian during the years of dictatorship, where we encounter a lot of censorships in translation, such as: Vicente Blasco lbanez, Lope de Vega, Pablo Neruda, Mariano Azuela Gonzales, Armando Salinas Lopez, Federico Garcia Lorca, Gabriel Garcia Marquez, Miguel Angel Asturias, Ernesto Castro, Aquilino Ribeiro, Maria Alise Barozo, Romulo Gallegos, Julio Cortazar, Isabel Allende, etc. Spanish literary translations albeit censored and not fully translated helped the reader to approach closer to Spanish reality. Another work which found support of the Albanian reader was theatrical works of Federico Garcia Lorca 'The House of Bernarda Alba ", a work in which reflected Spanish society in the era of Franco during the Spanish Civil War in the years 1936-1939. House of Bernarda was not confined to the four walls, or in the black clothes of female characters but was the personification of the state and the Spanish government and the poor socio-economic state. Some of the aforementioned authors were brought back again in Albanian language after 90 years because during the long years of dictatorship they had been censored. One of these Spanish or Latin American authors, whose novel was not published in full but the translation was censored, is the Chilean writer Isabel Allende, with her work 'House of Spirits'. The text was originally published with interference inside, because of censorship that existed in that period. The second edition after the 90 s created the ultimate possibility of communicating with the entirety of her novels. Spanish literary translations in Albanian language had an extraordinary increase in the year ' 56 and onwards reaching a record of 49 literary translations until 1988. Two years later, with the fall of the dictatorship translations would be allowed to be completed and the readers, already Spanish literature enthusiasts had the opportunity to become acquainted and to read contemporary Spanish and Latin American authors. From 1990 until April 2017 the Albanian reader has had the opportunity to read about 76 Spanish literary translations.

\section{Table Nr.1}

\begin{tabular}{|l|l|}
\hline \multicolumn{2}{|l|}{ Chronology of Spanish literary translations in Albania } \\
\hline Period: 1928 - 1944: & Translated works: 10 \\
\hline Period: 1956 - 1988: & Translated works: 49 \\
\hline Period: 1990 - 2017: & Translated works: 76 \\
\hline
\end{tabular}

Albania, country of eagles with an ancient history but not very well known by the Spanish state has such a wide range of translations. If we take a look at the history, we may note that there are various events, although few in number linking the two nations. Historical relations between Albania and Spain are too few, not to say somewhat non-existent. With the opening of the Spanish Embassy in Tirana, Albania, in 2006 and the following years it is made possible and continues to work from both sides to get as much cooperation in various cultural, social, economic and political fields. It is therefore not surprising the fact that there is a somewhat small number of literary translations, compared to the Spanish in Albanian. The first literary works in Spanish from Albanian language dates back to 1973, of Ismail Kadare's novel "The General of the Dead Army", neatly translated by Ramon Sanchez Lizarralde. This novel was very well received by the Spanish reader and had a great resonance in the Spanish press. The first literary translations from Albanian into Spanish, made possible by the translator Ramon Sanchez Lizarralde, a graduate of the University of Tirana, Faculty of History and Philology of Albanian language, in 1983, will be a cultural window but also a bridge to Albanian literature, particularly affecting closely a true but distant reality for the Spanish state itself. The first literary books that were translated into Spanish language were the novels of Ismail Kadare, with various themes which enabled recognition in a broader aspect of the eagles' country. Of the many titles by which there is a historical reality or even unknown Albanian customs for the Spanish people, we can mention the cruelty of rivalry between Orthodox and Catholics in the novel 'Constantine and Doruntine', the parable against totalitarianism and totalitarian evil in the novel "The Palace of dreams", the divorce of Albania with the Soviet Union in "The great winter" or revenge and bloodhood in canon in 'Broken April', the theme of which was received very well by the Spanish reader, enabling more closely recognition of literary culture but also of local customs. Spanish translator Ramon Sanchez Lizarralde has translated about 30 novels of the Albanian writer Ismail Kadare over 25 years, giving an invaluable contribution not only to the culture and the Albanian state to be recognized more closely in Spain but also by building a connecting cultural bridge between these two countries. Although the writer Ismail Kadare has the largest number of literary translations in Spanish language, thanks to translator R. S. Lizarralde who was also 'Albanian voice' in Spain, there are also some other 
writers whose works are in Spanish bookstores. Among them we can mention: Fatos Kongoli, Petraq Risto, Bashkim Shehu, etc.

\section{Table Nr.2}

Chronology of Albanian literary translations in Spain

\begin{tabular}{|l|l|l|}
\hline Author & Period & Nr. of publishings \\
\hline Ismail Kadare & $1973-2014$ & 64 \\
\hline Agron Tufa, Ervin Hativi, Gentian Çoçoli & 2004 & 1 \\
\hline Petraq Risto & 2008 & 1 \\
\hline Starova Luan & 2008 & 1 \\
\hline Fatos Kongoli & $2009-2014$ & 7 \\
\hline
\end{tabular}

Although fewer in number, literary translations in Spanish helped escort a culture, tradition and wider recognition of the Albanian state, which until four decades ago was almost unknown to the Spanish people. In a research done on the internet and in social networks it is noticed that the translation of literary works, has created a new image but also more positive image in the eyes of the Spanish reader towards the Albanian state. By reading the Albanian works, the reader is familiar with the Spanish dictatorship, history, events, expressing traditions, loyalty but also hospitality as one of the most significant features of our country. The same thing is noticed in the Albanian social networks where there are a lot of blogs or various literary forums where discussion on Spanish and the Latin American literature, as well as the importance of translation of the most prominent literary works. Today, literary translations, unlike the dictatorial period of the Albanian state, coming into Albanian from the original language but also without censorship, allowing even closer and closer recognition of cultures.

\section{Concluding Remarks}

In conclusion, we can say that literary translations are not only a bridge between countries, but also help to expand the horizon by unifying elements between the respective cultures. Literary translation is not only a literary product of a novel or language, but it is also a value adjustment from one culture to another. It is the only bridge which brings together countries and cultures in order to create a universal cultural circuit.

\section{References:}

[1] El espanol: lenguaviva. Informe 2016,I nstituto Cervantes, http://www.cervantes.es/imagenes/File/prensa/EspanolLenguaViva16.pdf

[2] Salinas Viereck, Roberto, La traduccion como instrumento y estetica en la literatura hispanoamericana del siglo XVI, Universidad Complutense de Madrid, 2003.

[3] Ajazi, Edlir, Aspekte teorike dhe praktike tëpeerkthimit, Doctoral thesis. University of Tirana, Tiranë.

[4] Ajazi, Edlir, Aspekte teorike dhe praktike të përkthimit, Doctoral thesis, University of Tirana, Tiranë.

[5] Luis Estevez, Jose Alberto, Las traducciones escritas de letras de canciones: Bob Dylan en Espana (19712006), Universidad de Laguna, Curso 2009/2010, Tesis Doctorales.

[6] Nida, Eugene Albert, Language Structure and Translation: Essays, Stanford University Press, California, 1975.

[7] Pema, Alket, "Mbi përkthimin nëgjuhën shqipe tëpoezise"sëUolt Uitmanit", Doctoral thesis, University of Tirana, 2014.

[8] Llacer Llorca, Eusebio, Sobre la traduccion: Ideas tradicionales y teorias contemporanes, Universitat de Valencia, 2004.

[9] Vukovic, Jovanka, Como definimos el concepto de traduccion?, Cagnolati, Beatriz. La Traductologia: Miradas para comprender su complejidad, Universidad Nacional de La Plata, 2012.

[10] Nushi, Admira. Don Kishoti, ky humbës fitimtar. Doctoral thesis, University of Tirana, Tiranë. 2015. 